\title{
Atypical Fibroxanthoma
}

\author{
Akio Sakamoto \\ Department of Orthopaedic Surgery, Graduate School of Medical Sciences, Kyushu University, \\ Fukuoka, Japan.
}

\begin{abstract}
Atypical fibroxanthoma (AFX) is a nodular dermal ulcerative lesion with a favorable prognosis. AFX most commonly occurs on sun-exposed skin in elderly individuals. AFX is characterized by its association with ultraviolet radiation, not only from a clinical aspect, but also from a molecular aspect. Making a diagnosis of AFX is challenging, and it is important to differentiate it from squamous cell carcinoma and malignant melanoma. Histological features and combined immunohistochemical markers are necessary for a definitive diagnosis (i.e., an absence of immunostaining for cytokeratins, S100 and HMB45 in AFX is helpful for excluding both squamous cell carcinoma and malignant melanoma). AFX, as well as MFH (malignant fibrous histiocytoma), is a fibrohistiocytic lesion with myofibroblastic differentiation. AFX is considered to be a different lesion from MFH. AFX and MFH might share the same pathway which determines their morphology. However, they may have different pathways in development which determine their biological behavior.
\end{abstract}

Keywords: atypical fibroxanthoma, malignant fibrous histiocytoma, squamous cell carcinoma, malignant melanoma

\section{Introduction}

\section{History}

The term, "atypical fibroxanthoma (AFX)", was proposed by Helwig in 1963 for a lesion that was considered to demonstrate a reactive process (Helwig EB, 1963). This led to the establishment of the distinct clinicopathological features of AFX (Fretzin DF and Helwig EB, 1973).

\section{Clinical features}

AFX has been described in two clinical settings. More commonly, the tumor occurs on sun-exposed skin in elderly individuals. The majority of tumors are on the scalp, face, ears and upper limbs (Mirza $\mathrm{B}$ and Weedon D, 2005). In its less common form, the tumor occurs on the limbs and trunk when there is a lack of association with sun exposure in young individuals (Dahl I, 1976). Interestingly, AFX develops in organ transplant recipients who may be in a state of immunosuppression (Hafner $\mathrm{J}$ et al. 1999; Kanitakis J et al. 1996; Paquet P and Pierard GE, 1996). There have been rare reports of cases of multiple tumors (Mirza B and Weedon D, 2005; Nadjem MA et al. 1988). Furthermore, it has been reported that there is a predominance in men $(70 \%$ men; $30 \%$ women). The average age is reported to be 71.9 years, ranging from 29-91 years (Mirza B and Weedon D, 2005).

\section{Histological features}

AFX is a nodular dermal ulcerative lesion which typically shows rapid growth (Fig. 1). The color of AFX varies from tan to light-brown. The size is usually less than $2 \mathrm{~cm}$ in diameter (Enzinger FM and Weiss SW, 2001; Fretzin DF and Helwig EB, 1973) and the average preoperative size has been reported to be $1.7 \mathrm{~cm}$ (Seavolt M and McCall M, 2006). About half the cases are ulcerated (Mirza B and Weedon D, 2005) (Fig. 2).

AFX is composed of spindle, plump, epithelioid and bizarre cells, in various proportions, arranged in haphazard, vaguely fascicular or storiform patterns (Figs. 3, 4). It has been reported that spindle cells predominated in 72 percent of AFX cases (Mirza B and Weedon D, 2005). Multinucleated giant tumor cells are scattered. The nuclei of the lesion may be hyperchromatic and multilobulated. In general,

Correspondence: Akio Sakamoto, Department of Orthopaedic Surgery, Graduate School of Medical Sciences, Kyushu University, 3-1-1 Maidashi, Higashi-ku, Fukuoka, 812-8582, Japan. Tel: +81(Japan) 92-6425488; Fax: +81(Japan) 92-642-5507; Email: akio@med.kyushu-u.ac.jp 


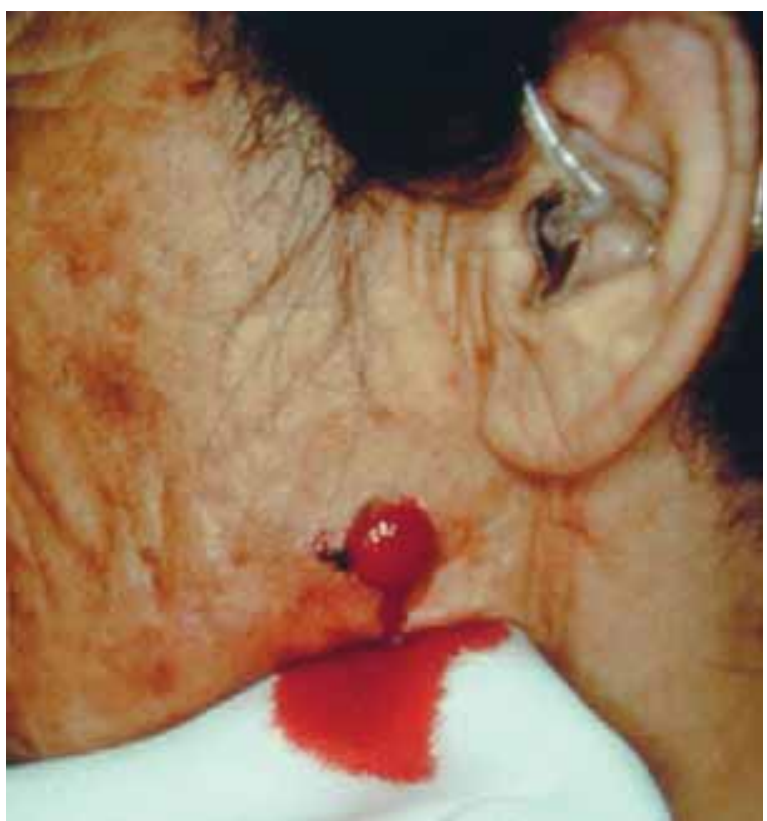

Figure 1. The facial lesion is protuberant and ulcerative, bleeding easily.

numerous mitotic figures, including atypical ones, can be seen (Enzinger FM and Weiss SW, 2001; Fretzin DF and Helwig EB, 1973) (Fig. 5). Some cells of the lesion may contain vacuolated and lipid-containing cytoplasm similar to xanthoma. This provided the origins for the name of atypical "xanthoma" (Dettrick A and Strutton G, 2006) (Fig. 6). Solar elastosis associated with ultraviolet (UV)-radiation has been commonly observed (Fretzin DF and Helwig EB, 1973; Sakamoto A et al. 2001a). Appendage involvement within the lesion, which is suggestive of undestroyed adnexal structures, is frequently seen (Sakamoto A et al. 2002) (Fig. 7). In addition to the classical AFX features, there have been reports of rare variants, including clear cells, osteoclastic giant cells, pigmented, osteoid, chondroid or granular cells and plaque-like cells (Crowson AN et al. 2002; Dettrick A and Strutton G, 2006; Fretzin DF and Helwig EB, 1973; Weedon D and Strutton G, 2002). Cases of AFX with prominent sclerosis and hyalinization have been also reported (Bruecks AK et al. 2003).

Since the initial description of AFX, the lesion has been a source of much controversy. Because of the histological similarity between AFX and malignant fibrous histiocytoma (MFH), AFX has been commonly regarded as a superficial variant of $\mathrm{MFH}$ (Enzinger FM and Weiss SW, 2001). MFH is one of the most common sarcomas occurring deep within soft tissue (Enzinger FM and Weiss SW, 2001). Most AFX cases (80\%) are restricted to the reticular dermis. The lesion may extend into the upper one-third of the subcutaneous adipose tissue (Mirza B and Weedon D, 2005). Currently, AFX is considered to be different from MFH. Size and depth are important in the differentiation between $\mathrm{AFX}$ and MFH. If a tumor extensively involves the subcutis, penetrates the fascia and muscle, or displays necrosis or perineural and vascular invasion, it should be diagnosed as MFH (Enzinger FM and Weiss SW, 2001). Extension into deeper structures like the parotid gland has been reported (Skoulas IG et al. 2001). However, it may be better to characterize such cases as MFH (Fish FS, 1996; Sankar $\mathrm{NM}$ et al. 1998). Previously reported cases of AFX may need to be reviewed carefully for a more precise diagnosis based on the current clinical and histologic criteria.

When AFX is less pleomorphic, it is indistinguishable from leiomyosarcoma (Calonje et al. 1993). Histologically, being different from AFX, leiomyosarcoma has typically distinct fascicles containing cells with characteristic blunt-ended nuclei, and cytoplasmic glycogen is often abundant (Enzinger FM and Weiss SW, 2001). Dermatofibrosarcoma protuberans (DFSP) is another differential diagnosis from AFX. DFSP is a nodular cutaneous tumor and it has been considered as a fibroblastic, histiocytic and neural tumor. Microscopically, the main portion of DFSP is composed of a uniform population of slender fibroblasts arranged in a distinct, often monotonous storiform pattern. CD34 is expressed on hematopoietic stem cells and on vascular endothelial cells and it has been reported to be a marker of DFSP (Enzinger FM and Weiss SW, 2001), while the expression of CD34 is absent in AFX (Krustrup D et al. 2006).

Besides MFH and leiomyosarcoma, the major differential diagnosis includes pleomorphic and spindled variant of squamous carcinoma and malignant melanoma. Basal cell carcinoma and keratoacanthoma are also differential diagnoses. Histologically, in the differentiation between AFX and squamous cell carcinoma, there is neither junctional activity nor focal epithelial differentiation in AFX (Enzinger FM and Weiss SW, 2001). In a case of clear cell variant of AFX, additional differential diagnoses should include clear cell sarcoma (malignant melanoma of soft parts), 


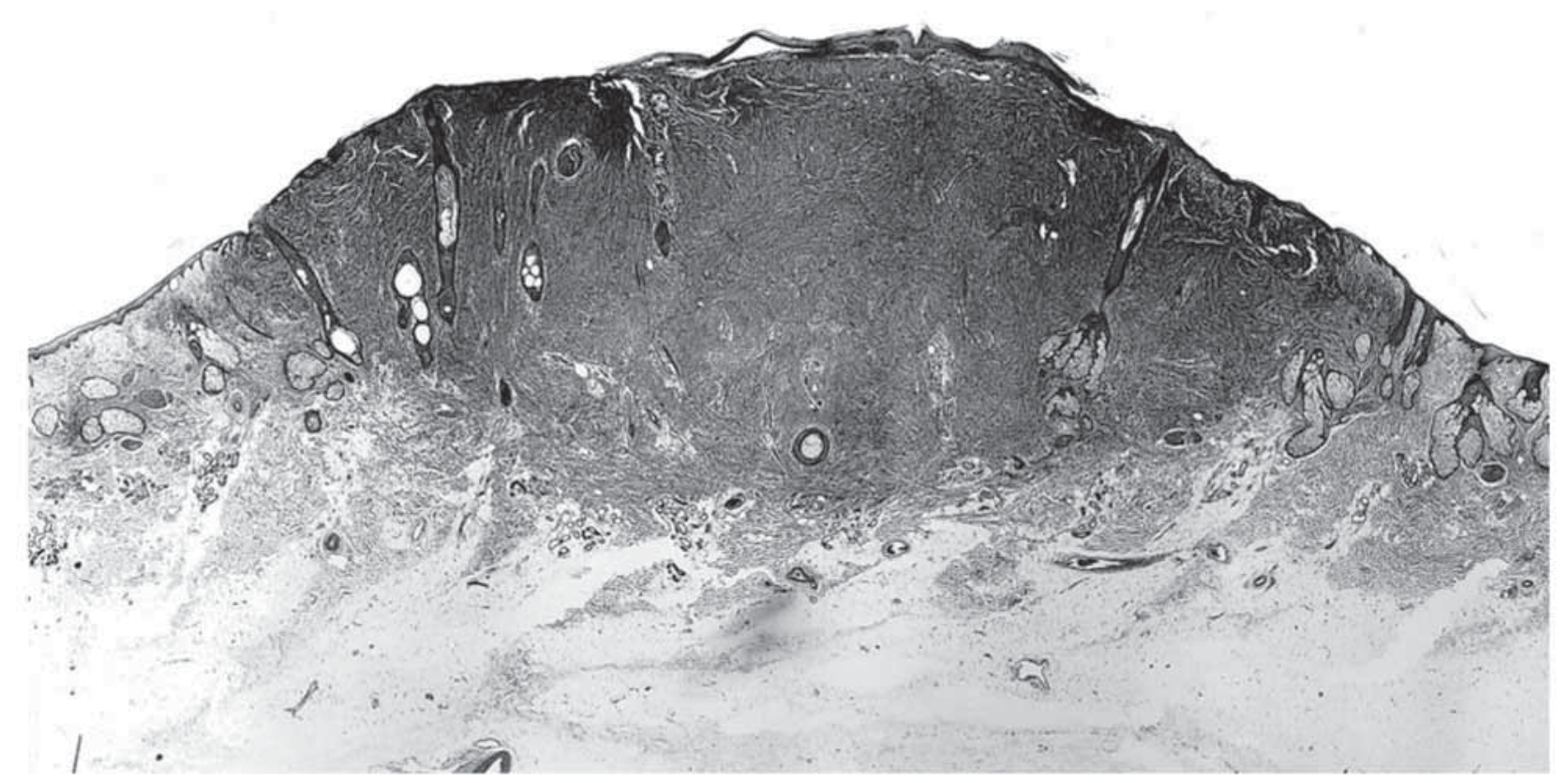

Figure 2. Atypical fibroxanthoma shows an exophytic cellular nodule with ulceration of the overlying epidermis. The nodule is restricted to the reticular dermis. (Hematoxylin and eosin, original magnification, $x 8$ ).

balloon cell melanoma, metastatic renal cell carcinoma, sebaceous carcinoma and clear cell hidradenocarcinoma (Cai JP and Randall B, 2006; Crowson AN et al. 2002; Kao GF et al. 1992). Similarly, granular cell variant of AFX may need to be differentiated from granular cell tumor, including its malignant counterpart (Rudisaile SN et al. 2005).

\section{Differential Diagnosis in Terms of Immunohistochemistry}

Making a diagnosis of AFX is challenging and the diagnosis of AFX should be made by exclusion of the differential diagnoses. Combined immunohistochemical markers are necessary for a definitive diagnosis (Table 1) (Hartel PH et al. 2006; Kanitakis J et al. 2000; Krustrup D et al. 2006). Absent immunostaining for cytokeratins, S100 and HMB45 in AFX is helpful for excluding both squamous cell carcinoma and malignant melanoma (Hultgren TL and DiMaio DJ, 2007; Mirza B and Weedon D, 2005). Cytokeratins are epithelial markers and they are positive for squamous cell carcinoma. S100 protein is widely used as a Schwann cell marker and it is also positive for malignant melanoma. HMB45 and MART-1 are melanocyte-specific markers, and these antibodies recognize gp 100 and PMel17, respectively (SmithZagone MJ et al. 2004). However, it should be remembered that some poorly differentiated squamous cell carcinomas may not express cytokeratin, and S100 and HMB45 are not detectable in all malignant melanoma cases (Lodding P et al. 1990; Wick MR et al. 1988). Furthermore, dendritic cells within AFX may express S100 (Longacre TA et al. 1993; Ricci A Jr et al. 1988; Winkelmann RK and Peters MS, 1985). Focal HMB45 and MART-1 expression in the giant cells of an AFX has been reported (Smith-Zagone MJ et al. 2004).

CD10, or the common acute lymphoblastic leukaemia antigen (CALLA), is a cell-surface neutral endopeptidase which is expressed by lymphoid precursor cells and by B lymphoid cells of germinal center origin (Ritz J et al. 1980). CD10 is reported to be a useful marker for AFX, because of its high positivity rate $(95 \%-100 \%)$ (Mirza B and Weedon D, 2005; Sakamoto A et al. 2002; Weedon D et al. 2005). Although one-third of malignant melanoma cases have been reported to be positive for CD10, the staining was less intense and tended to accumulate within the surrounding stroma (Hultgren TL and DiMaio DJ, 2007). On the other hand, about half the cases of squamous cell carcinoma showed 
positivity for CD10, but the staining was also weak in most of the cases, involving less than $25 \%$ of cells (Hultgren TL and DiMaio DJ, 2007).

CD99, or p30/32, is a glycoprotein product of the MIC2 gene. It was originally utilized in immunohistochemistry as a unique marker for Ewing sarcoma. CD99 has been reported to be a useful marker of AFX, but the positivity rate for CD99 has been reported to vary between 35\% (Mirza B and Weedon D, 2005) and 73\% (Monteagudo C et al. 2002) of AFX cases, although none of the squamous cell carcinoma cases have been reported to be positive for CD99 (Monteagudo C et al. 2002). However, it has been revealed that $10 \%$ (Monteagudo C et al. 2002) and 60\% (Wilkerson AE et al. 2006) of malignant melanomas show positive staining for CD99.

Procollagen is secreted by fibroblasts into the extracellular matrix, where it is cleaved to form collagen. Procollagen-1 staining was strongly positive in $87 \%$ of AFX cases (Jensen K et al. 2004). On the other hand, positive staining in the tumor cells was observed in about one-third of the desmoplastic squamous cell carcinomas and desmoplastic malignant melanomas (Jensen K et al. 2004).

Taken together, these findings suggest that there is no specific sole immunohistochemical marker of AFX that would help differentiate it from squamous cell carcinoma and malignant melanoma. A combination of immunohistochemical markers is important to make a clear diagnosis of AFX.

\section{AFX is a Unique Entity, in Comparison to MFH}

AFX, as well as MFH, is a fibrohistiocytic lesion with myofibroblastic differentiation (Sakamoto A et al. 2002). A histiocytic/macrophage marker,

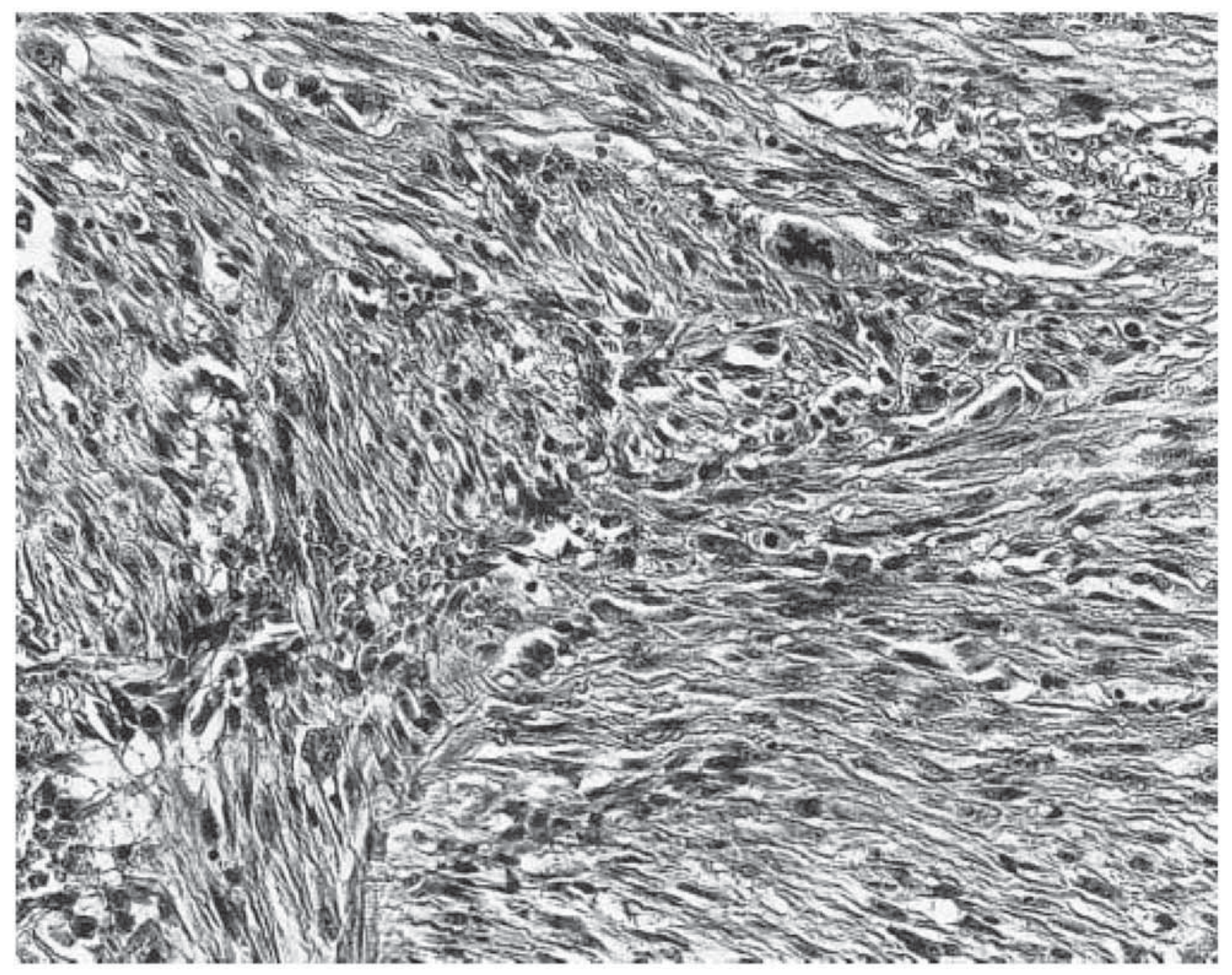

Figure 3. Atypical fibroxanthoma shows a proliferation of atypical spindled cells in a haphazard or disorderly pattern. (Hematoxylin and eosin, original magnification, $\mathrm{x} 180$ ). 


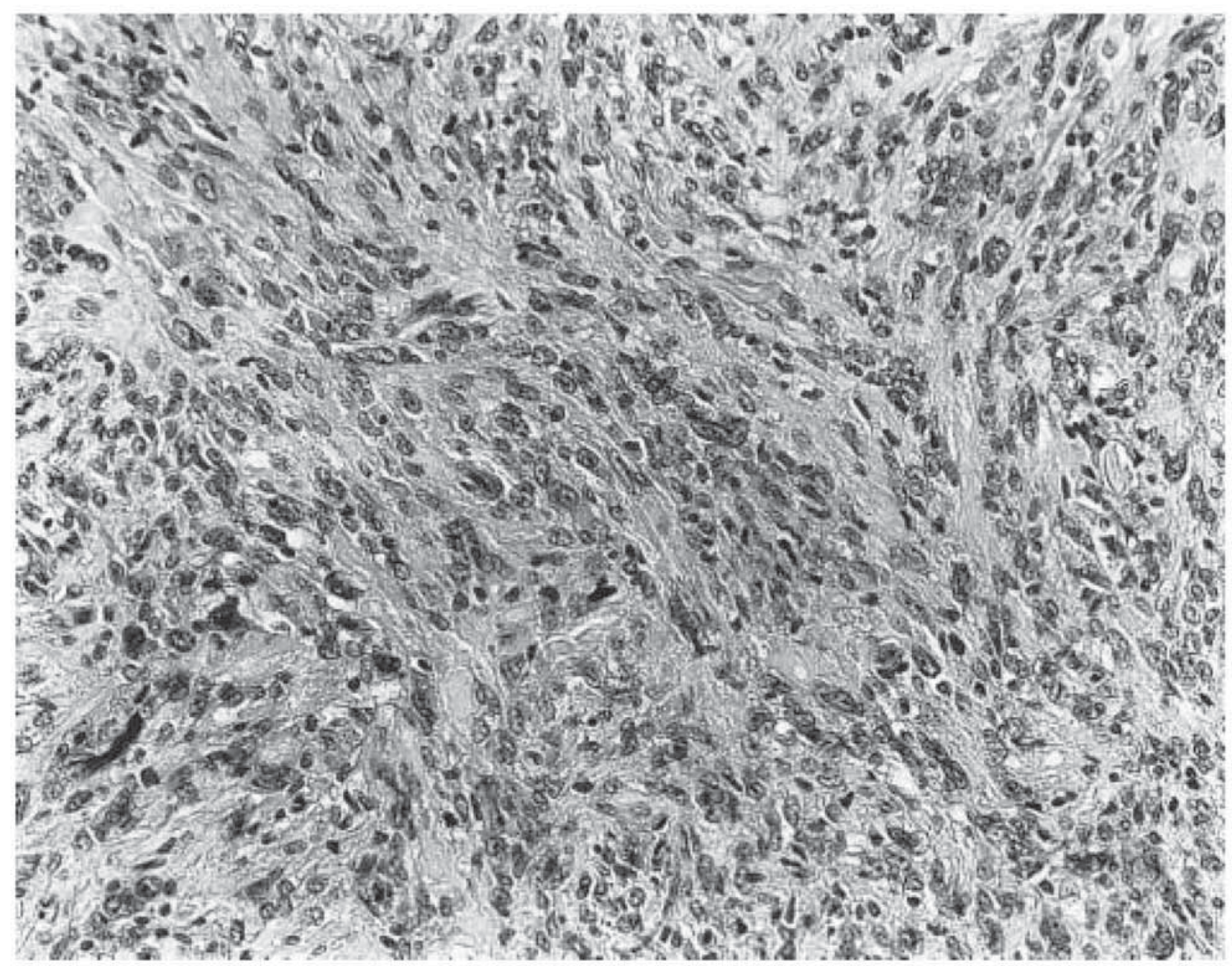

Figure 4. Atypical fibroxanthoma shows plump pleomorphic epithelioid cells. (Hematoxylin and eosin, original magnification, $\mathrm{x} 180$ ).

CD68, is positive in more than half of all AFX cases (Hultgren TL and DiMaio DJ, 2007; Smith-Zagone MJ et al. 2004). However, CD68 is also detectable in $86 \%$ of malignant melanoma cases (Pernick NL et al. 1999). As seen in MFH, AFX has immunoreactivities for several myogenic/myofibroblastic markers comprising desmin, alpha-smooth muscle actin and musclespecific actin. Calponin and h-caldesmon are cytoskeleton-associated actin-binding proteins. They have been reported to be more specific myogenic markers. Positive or negative expression for calponin and negative expression for $\mathrm{h}$-caldesmon in AFX is useful for distinguishing it from leimyosarcoma, which has smooth muscle differentiation characterized by positive findings for calponin and h-caldesmon, but such expression is shared by both AFX and MFH (Sakamoto A et al. 2002).
A high percentage of CD10 expression in AFX could be a marker from leiomyosarcoma, in which about half the cases of leiomyosarcomas are positive for CD10 (Sakamoto A et al. 2007). On the other hand, CD10 has been expressed in almost all the cases of MFH, as well as AFX (Sakamoto A et al. 2007; Weedon D et al. 2005). However, the number of AFX cases with moderate/strong or diffuse immunoreactivity for CD99 is significantly larger than that of MFH cases (Hartel PH et al. 2006). On the other hand, the LN-2 (CD74) antigen is the MHC-II complex and it is found on B cells, macrophages, monocytes, Reed-Sternberg cells and other B-cell proliferations. AFX and MFH may have been differentiated based upon positivity for CD74, in which reduced immunoexpression for CD74 in AFX is characterized compared to that in MFH (Lazova R et al. 1997). Further examination will be necessary in order to confirm the reliability 


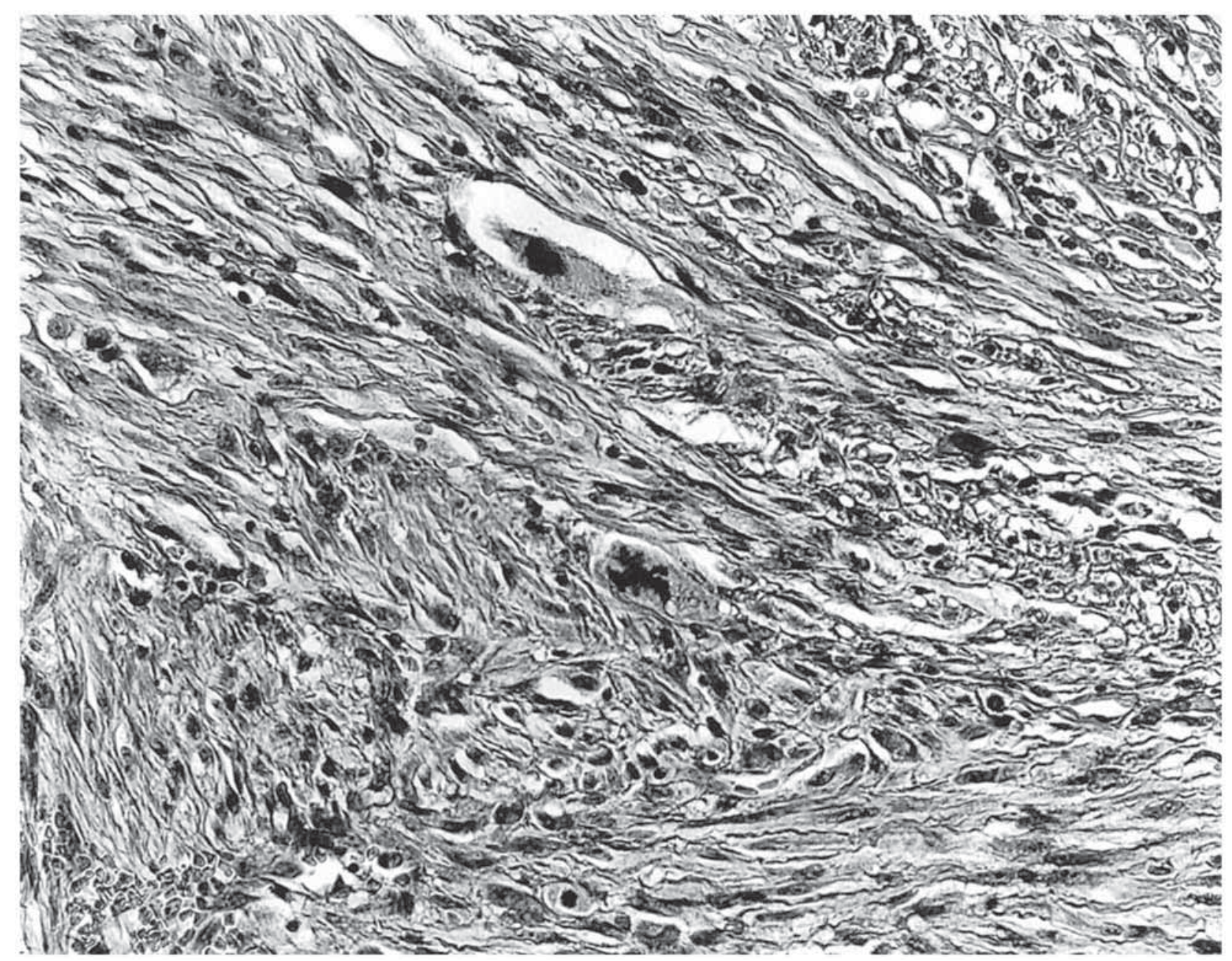

Figure 5. Atypical fibroxanthoma. Atypical mitosis can be observed. (Hematoxylin and eosin, original magnification, x200).

of CD74 as a marker with which to differentiate between AFX and MFH (Ly H et al. 2004).

It seems that AFX and MFH share histological and immunological features. There are also similarities between the two lesions in terms of a high proliferation rate in the case of the proliferation markers of PCNA and MIB-1 (Oshiro Y et al. 1995; Sakamoto A et al. 2007), as well as similarities regarding apoptotic counts and bcl 2 expression, which is a regulator protein for apoptosis (Westermann FN et al. 1997). However, from a molecular aspect, AFX is characterized by a diploid pattern, while the majority of chromosomal changes in $\mathrm{MFH}$ are of an aneuploid pattern (Oshiro Y et al. 1995; Worrell JT et al. 1993). H-, K-, and N-ras gene mutations are not present in AFX, whereas MFH has $\mathrm{H}$ - and $\mathrm{K}$-ras gene mutations, although only a small number of cases was studied (Sakamoto A et al. 2001b). In a comparison between MFH and leiomyosarcoma, a previous report supported the opinion that MFH may represent a morphological pathway in tumor progression of leiomyosarcoma according to the same shared chromosome abnormality (Sabah M et al. 2005). It is also possible that AFX and MFH share the same pathway which determines their morphology, but that AFX and MFH may have different pathways of biological behavior which determine their clinical behavior. In a previous report, comparative genomic hybridization (CGH) analysis demonstrated similarities between AFX and undifferentiated pleomorphic sarcoma, or MFH. The CGH data demonstrated that genetic alterations on chromosomes $9 p$ and $13 q$ seem to suggest a common pathogenetic pathway (Mihic-Probst D et al. 2004).

\section{Molecular Mechanism}

AFX typically occurs on the head and neck of sunexposed skin. This fact has long suggested a role 


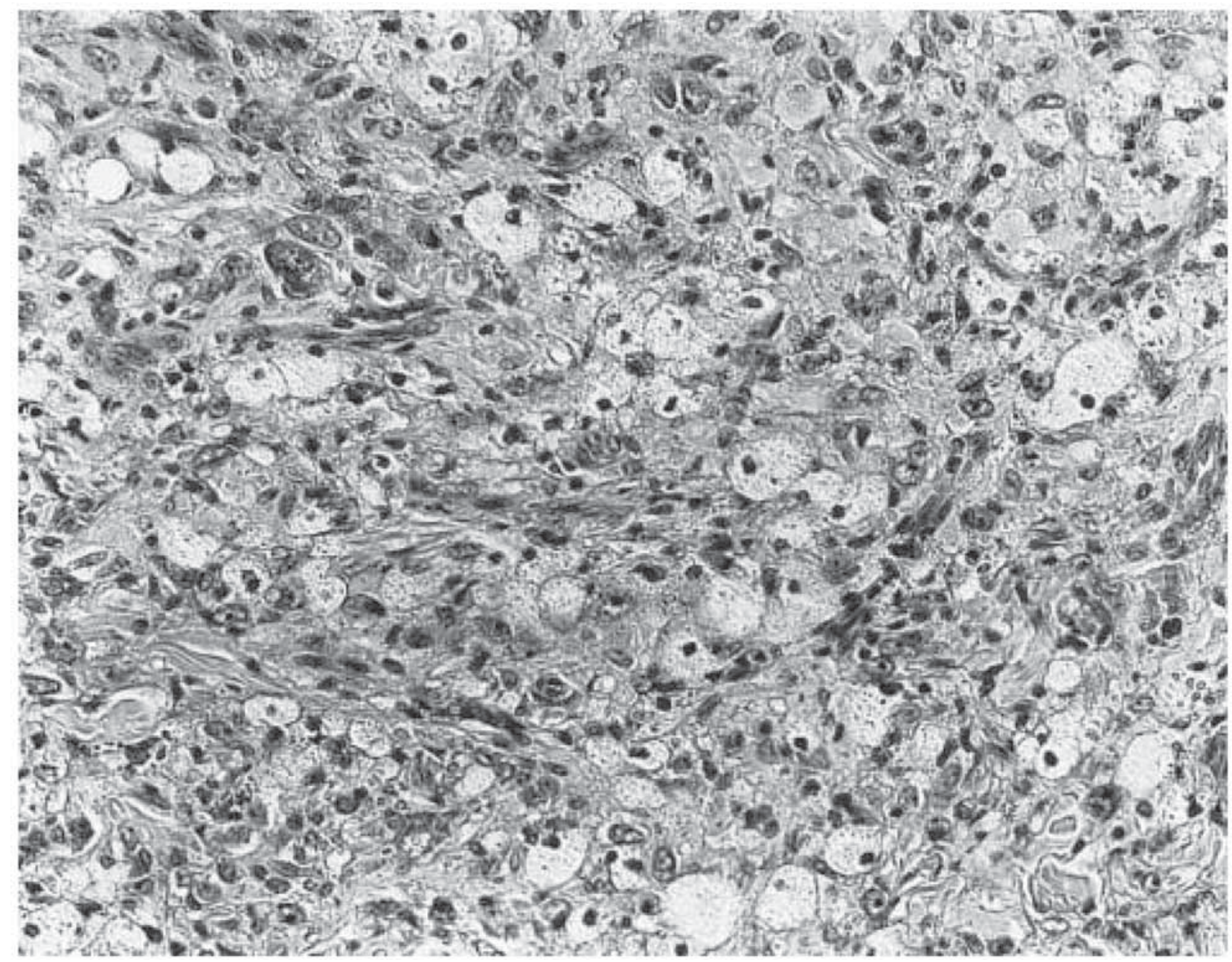

Figure 6. Atypical fibroxanthoma. Frequent xanthoma cells are visible. (Hematoxylin and eosin, original magnification, x200).

for sun exposure in the tumorigenesis of AFX. UV radiation from sunlight is an important risk factor for skin cancer (Aragane Y et al. 1998). DNA damage caused by UV is primarily repaired by the nucleotide excision repair (NER) pathway. The tumor suppressor protein p53 is a transcriptional activator and it is involved in cell cycle control, apoptosis and genome instability. p53 also plays a direct role in NER (Lee S et al. 1995; Reed M et al. 1995). The predominant mutation patterns of $\mathrm{C}-\mathrm{T}$ transitions and CC-TT double transitions at dipyrimidine sites in the p53 gene are considered to be characterized by UV radiation (Brash DE et al. 1991; Miller JH, 1985), thereby suggesting a central role of UV radiation in the development of AFX (Dei Tos et al. 1994). The association between decreased DNA repair ability and AFX may be supported by a report showing that patients with xeroderma pigmentosum had AFX, and it is known that xeroderma pigmentosum is related to DNA repair defects (Dilek FH et al. 2000; Weedon D and Strutton G, 2002).

The formation of DNA photoproducts by UV radiation is reported to be responsible for the development of skin cancer (Pfeifer GP, 1997). Among these photoproducts, cyclobutane pyrimidine dimers (CPDs) and pyrimidine-pyrimidone (6-4) photoproducts (64PPs) are important as they are involved in mutagenesis and carcinogenesis (Hart RW et al. 1977; Moan J and Peak MJ, 1989). DNA photoproducts are removed by NER. DNA photoproducts can interfere with the binding of several important cell-cycle regulatory and DNA damage-responsive transcription factors (Tommasi $\mathrm{S}$ et al. 1996). It has been reported that the accumulation of DNA photoproducts may play an important role in the pathogenesis of AFX (Sakamoto A et al. 2001a). 


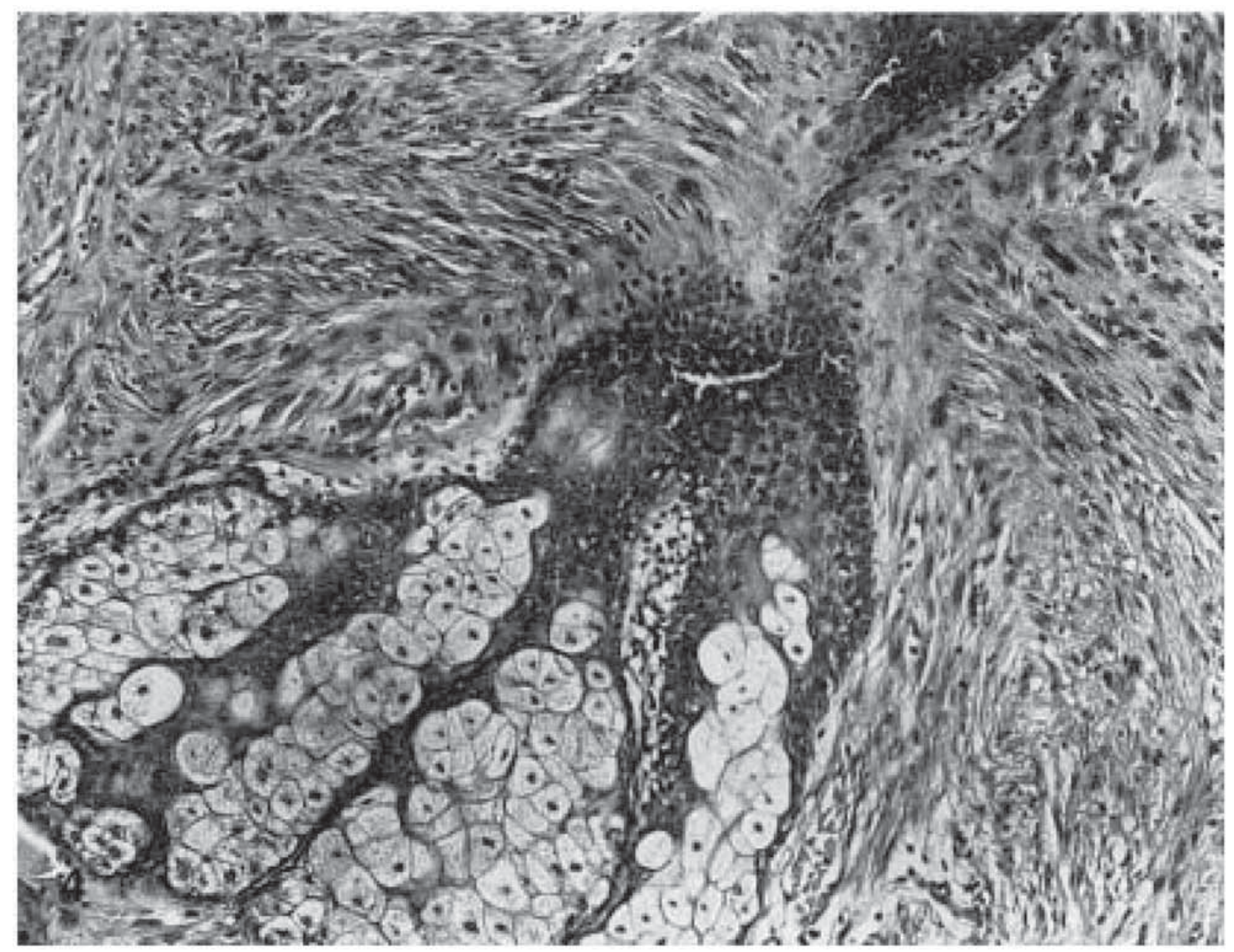

Figure 7. Atypical fibroxanthoma. Appendage involvement within the lesion can be observed. (Hematoxylin and eosin, original magnification, $\mathrm{x} 100)$.

Table 1. Immunohistochemical profiles of AFX and its differentiations.

\begin{tabular}{|c|c|c|c|c|c|c|c|}
\hline Antibody & Marker & AFX & MFH & LMS & SCC & MM & DFSP \\
\hline Vimentin & Mesenchymum & + & + & + & - & + & + \\
\hline Cytokeratin & Epithelium & - & - & - & + & - & - \\
\hline EMA & Epithelium & - & - & - & + & - & - \\
\hline S100 & Schwann cell & - & - & - & - & + & - \\
\hline HMB45 & Melanocyte & - & - & - & - & + & - \\
\hline MART-1 & Melanocyte & - & - & - & - & + & - \\
\hline SMA & Myocyte/myofibroblast & $+/-$ & $+/-$ & + & - & - & $+1-$ \\
\hline Desmin & Myocyte/myofibroblast & $+/-$ & $+/-$ & + & - & - & $+/-$ \\
\hline Calponin & Myocyte/myofibroblast & $+/-$ & $+/-$ & + & - & - & - \\
\hline h-Caldesmon & Myocyte & - & - & + & - & - & - \\
\hline CD10 (CALLA) & Lymphoid precursor & + & + & $+1-$ & $+1-$ & $+1-$ & $+1-$ \\
\hline CD34 & Endothelium & - & - & - & - & - & + \\
\hline CD68 & Histiocyte/macrophage & + & + & - & - & - & - \\
\hline CD74 (LN-2) & MHC-II complex & $+/-$ & + & $\mathrm{N}$ & $\mathrm{N}$ & $\mathrm{N}$ & $+/-$ \\
\hline CD99 (p30/32) & MIC2 gene product & $+/-$ & $+/-$ & $-^{*}$ & - & $+/-$ & $-^{*}$ \\
\hline Procollagen-1 & Procollagen & + & $+^{*}$ & $+1-$ & $+/-$ & $+/-$ & + \\
\hline
\end{tabular}

Abbreviations: AFX: atypical fibroxanthoma; MFH: malignant fibrous histiocytoma; LMS: leiomyosarcoma; SCC: squamous cell carcinoma; MM: malignant melanoma; DFSP: dermatofibrosarcoma protuberans; EMA: epithelial membrane antigen; SMA: smooth muscle actin; CALLA: common acute lymphoblastic leukaemia antigen; $\mathrm{N}$ : not reported; +: positive in most cases; +l-: positive but not always; -: negative in most cases; *: small number of cases has been assessed. 


\section{Prognosis and Treatment}

There are no clear recommendations regarding the treatment of AFX (Seavolt M and McCall M, 2006). However, AFX is usually treated surgically, and the recurrence rate has been reported to range between 5\% (Weedon D and Strutton G, 2002) and 10\% (Fretzin DF and Helwig EB, 1973; Giuffrida TJ et al. 2004). Multiple local recurrence has rarely been reported (Jacobs DS et al. 1975). Metastases are uncommon and occur in approximately $1 \%$ of reported cases (Davis JL et al. 1997; Grosso $M$ et al. 1987). However, no recurrence or metastasis was observed in 89 AFX lesions (Mirza $B$ and Weedon D, 2005). Features associated with metastasis include recurrence, vascular invasion, large tumor, deep tissue invasion and tumor necrosis (Giuffrida TJ et al. 2004; Helwig EB and May D, 1986). It has been analyzed that these locally invasive and/or metastasizing lesions may have initially been MFH, squamous cell carcinoma or malignant melanoma, rather than AFX (Giuffrida TJ et al. 2004; Starink TH et al. 1977).

As for surgical margin, wide excision with 1 $\mathrm{cm}$ margins has been recommended in the past (Giuffrida TJ et al. 2004). However, there have been reports of Mohs microsurgery treatment for AFX with favorable results (Brown MD and Swanson NA, 1989; Davis JL et al. 1997; Huether MJ et al. 2001; Zalla MJ et al. 1997). Mohs microsurgery is an operation that removes the neoplasm and as little of the normal tissue as possible. During the surgery, a microscope is used to look at the neoplastic area in order to make sure that all of the neoplastic cells have been removed.

\section{Conclusion}

AFX is now believed to be a benign lesion centered in the dermis in the sun-exposed skin of the elderly or children with xeroderma pigmentosum or other conditions with defective DNA repair. Decreased DNA repair ability might be associated as a pathogenesis in AFX, although further examinations are necessary, in order to ascertain whether this is actually true or not. Making a diagnosis of AFX is challenging. The diagnosis should be made only after applying the stringent histological criteria and a broad panel of immunostains. AFX is thought to be a different lesion from MFH. AFX and MFH might share the same pathway which determines the morphology, but they may have different pathways which determine biological activity in a tumor-specific manner.

\section{Acknowledgements}

The English used in this manuscript was revised by Miss K. Miller (Royal English Language Centre, Fukuoka, Japan).

\section{References}

Aragane, Y., Kulms, D., Metze, D., Wilkes, G., Poppelmann, B., Luger, T.A. and Schwarz, T. 1998. Ultraviolet light induces apoptosis via direct activation of CD95 (Fas/APO-1) independently of its ligand CD95L. J. Cell. Biol., 140(1):171-82.

Brash, D.E., Rudolph, J.A., Simon, J.A., Lin, A., McKenna, G.J., Baden, H.P., Halperin, A.J. and Ponten, J. 1991. A role for sunlight in skin cancer: UV-induced p53 mutations in squamous cell carcinoma. Proc. Natl. Acad. Sci. U.S.A., 88(22):10124-8.

Brown, M.D. and Swanson, N.A. 1989. Treatment of malignant fibrous histiocytoma and atypical fibrous xanthomas with micrographic surgery. J. Dermatol. Surg. Oncol., 15(12):1287-92.

Bruecks, A.K., Medlicott, S.A. and Trotter, M.J. 2003. Atypical fibroxanthoma with prominent sclerosis. J. Cutan Pathol., 30(5):336-9.

Cai, J.P. and Randall, B. 2006. HMB-45 expression in a clear cell variant of atypical fibroxanthoma. J. Cutan Pathol., 33(2):186-8.

Calonje, E., Wadden, C., Wilson-Jones, E. and Fletcher, C.D. 1993. Spindlecell non-pleomorphic atypical fibroxanthoma: analysis of a series and delineation of a distinctive variant. Histopathology, 22(3):247-54.

Crowson, A.N., Carlson-Sweet, K., Macinnis, C., Taylor, J.R., Battaglia, T., LaMar, W.L., Minor, D., Sutter, S. and Hill, T. 2002. Clear cell atypical fibroxanthoma: a clinicopathologic study. J. Cutan Pathol., 29(6):374-81.

Dahl, I. 1976. Atypical fibroxanthoma of the skin. A clinico-pathological study of 57 cases. Acta. Pathol. Microbiol. Scand [A], 84(2):183-97.

Davis, J.L., Randle, H.W., Zalla, M.J., Roenigk, R.K. and Brodland, D.G. 1997. A comparison of Mohs micrographic surgery and wide excision for the treatment of atypical fibroxanthoma. Dermatol. Surg., 23(2):105-10.

Dei Tos, A.P., Maestro, R., Doglioni, C., Gasparotto, D., Boiocchi, M., Laurino, L. and Fletcher, C.D. 1994. Ultraviolet-induced p53 mutations in atypical fibroxanthoma. Am. J. Pathol., 145(1):11-7.

Dettrick, A. and Strutton, G. 2006. Atypical fibroxanthoma with perineural or intraneural invasion: report of two cases. J. Cutan Pathol., 33(4):318-22.

Dilek, F.H., Akpolat, N., Metin, A. and Ugras, S. 2000. Atypical fibroxanthoma of the skin and the lower lip in xeroderma pigmentosum. $\mathrm{Br}$. J. Dermatol., 143(3):618-20.

Enzinger, F.M. and Weiss, S.W. 2001. Soft tissue tumors, CV Mosby, St. Louis.

Fish, F.S. 1996. Soft tissue sarcomas in dermatology. Dermatol. Surg., 22(3):268-733.

Fretzin, D.F. and Helwig, E.B. 1973. Atypical fibroxanthoma of the skin. A clinicopathologic study of 140 cases. Cancer, 31(6):1541-1552.

Giuffrida, T.J., Kligora, C.J. and Goldstein, G.D. 2004. Localized cutaneous metastases from an atypical fibroxanthoma. Dermatol. Surg., 30(12 Pt 2):1561-4.

Grosso, M., Lentini, M., Carrozza, G. and Catalano, A. 1987. Metastatic atypical fibroxanthoma of skin. Pathol. Res. Pract., 182(3):443-7.

Hafner, J., Kunzi, W. and Weinreich, T. 1999. Malignant fibrous histiocytoma and atypical fibroxanthoma in renal transplant recipients. Dermatology, 198(1):29-32.

Hart, R.W., Setlow, R.B. and Woodhead, A.D. 1977. Evidence that pyrimidine dimers in DNA can give rise to tumors. Proc. Natl. Acad. Sci. U.S.A., 74(12):5574-8. 
Hartel, P.H., Jackson, J., Ducatman, B.S. and Zhang, P. 2006. CD99 immunoreactivity in atypical fibroxanthoma and pleomorphic malignant fibrous histiocytoma: a useful diagnostic marker. J. Cutan Pathol., 33(Suppl 2):24-8.

Helwig, E.B. 1963. Atypical fibroxanthoma. Tex State J. Med., (59):664.

Helwig, E.B. and May, D. 1986. Atypical fibroxanthoma of the skin with metastasis. Cancer, 57(2):368-76.

Huether, M.J., Zitelli, J.A. and Brodland, D.G. 2001. Mohs micrographic surgery for the treatment of spindle cell tumors of the skin. J. Am. Acad. Dermatol., 44(4):656-9.

Hultgren, T.L. and DiMaio, D.J. 2007. Immunohistochemical staining of CD10 in atypical fibroxanthomas. J. Cutan Pathol., 34(5):415-9.

Jacobs, D.S., Edwards, W.D. and Ye, R.C. 1975. Metastatic atypical fibroxanthoma of skin. Cancer, 35(2):457-63.

Jensen, K., Wilkinson, B., Wines, N. and Kossard, S. 2004. Procollagen 1 expression in atypical fibroxanthoma and other tumors. J. Cutan Pathol., 31(1):57-61.

Kanitakis, J., Bourchany, D. and Claudy, A. 2000. Expression of the CD10 antigen (neutral endopeptidase) by mesenchymal tumors of the skin. Anticancer Res., 20(5B):3539-44.

Kanitakis, J., Euvrard, S., Montazeri, A., Garnier, J.L., Faure, M. and Claudy, A. 1996. Atypical fibroxanthoma in a renal graft recipient. $J$. Am. Acad. Dermatol., 35(2 Pt 1):262-4.

Kao, G.F., Helwig, E.B. and Graham, J.H. 1992. Balloon cell malignant melanoma of the skin. A clinicopathologic study of 34 cases with histochemical, immunohistochemical, and ultrastructural observations. Cancer, 69(12):2942-52.

Krustrup, D., Rossen, K. and Thomsen, H.K. 2006. Procollagen 1-a marker of fibroblastic, and fibrohistiocytic skin tumors. J. Cutan Pathol., 33(9):614-8.

Lazova, R., Moynes, R., May, D. and Scott, G. 1997. LN-2 (CD74). A marker to distinguish atypical fibroxanthoma from malignant fibrous histiocytoma. Cancer, 79(11):2115-24.

Lee, S., Elenbaas, B., Levine, A. and Griffith, J. 1995. p53 and its 14 kDa C-terminal domain recognize primary DNA damage in the form of insertion/deletion mismatches. Cell., 81(7):1013-20.

Lodding, P., Kindblom, L.G. and Angervall, L. 1990. Metastases of malignant melanoma simulating soft tissue sarcoma. A clinico-pathological, light- and electron microscopic and immunohistochemical study of 21 cases. Virchows Arch. A Pathol. Anat. Histopathol, 417(5):377-88.

Longacre, T.A., Smoller, B.R. and Rouse, R.V. 1993. Atypical fibroxanthoma. Multiple immunohistologic profiles. Am. J. Surg. Pathol., 17(12):1199-209.

Ly, H., Selva, D., James, C.L. and Huilgol, S.C. 2004. Superficial malignant fibrous histiocytoma presenting as recurrent atypical fibroxanthoma. Australas J. Dermatol, 45(2):106-9.

Mihic-Probst, D., Zhao, J., Saremaslani, P., Baer, A., Oehlschlegel, C., Paredes, B., Komminoth, P. and Heitz, P.U. 2004. CGH analysis shows genetic similarities and differences in atypical fibroxanthoma and undifferentiated high grade pleomorphic sarcoma. Anticancer Res. 24(1):19-26.

Miller, J.H. 1985. Mutagenic specificity of ultraviolet light. J. Mol. Biol., 182(1):45-65.

Mirza, B. and Weedon, D. 2005. Atypical fibroxanthoma: a clinicopathological study of 89 cases. Australas J. Dermatol., 46(4):235-238.

Moan, J. and Peak, M.J. 1989. Effects of UV radiation of cells. J. Photochem. Photobiol. B., 4(1):21-34.

Monteagudo, C., Calduch, L., Navarro, S., Joan-Figueroa, A. and LlombartBosch, A. 2002. CD99 immunoreactivity in atypical fibroxanthoma: a common feature of diagnostic value. Am. J. Clin. Pathol., 117(1):126-31.

Nadjem, M.A., Graham, J.H. and Johnson, F.B. 1988. Lycopodium granuloma. J. Cutan Pathol., 15(2):120-3.

Oshiro, Y., Fukuda, T. and Tsuneyoshi, M. 1995. Atypical fibroxanthoma versus benign and malignant fibrous histiocytoma. A comparative study of their proliferative activity using MIB.-1, DNA flow cytometry, and p53 immunostaining. Cancer, 75(5):1128-1134
Paquet, P. and Pierard, G.E. 1996. Invasive atypical fibroxanthoma and eruptive actinic keratoses in a heart transplant patient. Dermatology, 192(4):411-3

Pernick, N.L., DaSilva, M., Gangi, M.D., Crissman, J. and Adsay, V. 1999. "Histiocytic markers" in melanoma. Mod. Pathol., 12(11):1072-7.

Pfeifer, G.P. 1997. Formation and processing of UV photoproducts: effects of DNA sequence and chromatin environment. Photochem. Photobiol., 65(2):270-83.

Reed, M., Woelker, B., Wang, P., Wang, Y. anderson, M.E. and Tegtmeyer, P. 1995. The C-terminal domain of 553 recognizes DNA damaged by ionizing radiation. Proc. Natl. Acad. Sci. U.S.A., 92(21):9455-9.

Ricci, A. Jr, Cartun, R.W. and Zakowski, M.F. 1988. Atypical fibroxanthoma. A study of 14 cases emphasizing the presence of Langerhans' histiocytes with implications for differential diagnosis by antibody panels. Am. J. Surg. Pathol., 12(8):591-8.

Ritz, J., Pesando, J.M., Notis-McConarty, J., Lazarus, H. and Schlossman, S.F. 1980. A monoclonal antibody to human acute lymphoblastic leukaemia antigen. Nature, 283(5747):583-5.

Rudisaile, S.N., Hurt, M.A. and Santa Cruz, D.J. 2005. Granular cell atypical fibroxanthoma. J. Cutan Pathol. (32):314-7.

Sabah, M., Cummins, R., Leader, M. and Kay, E. 2005. Leiomyosarcoma and malignant fibrous histiocytoma share similar allelic imbalance pattern at 9p. Virchows Arch., 446(3):251-8.

Sakamoto, A., Oda, Y., Itakura, E., Oshiro, Y., Nikaido, O., Iwamoto, Y. and Tsuneyoshi, M. 2001a. Immunoexpression of ultraviolet photoproducts and 553 mutation analysis in atypical fibroxanthoma and superficial malignant fibrous histiocytoma. Mod. Pathol., 14(6):581-8.

Sakamoto, A., Oda, Y., Itakura, E., Oshiro, Y., Tamiya, S., Honda, Y., Ishihara, A., Iwamoto, Y. and Tsuneyoshi, M. 2001b. H-, K-, and $\mathrm{N}$-ras gene mutation in atypical fibroxanthoma and malignant fibrous histiocytoma. Hum. Pathol., 32(11):1225-31.

Sakamoto, A., Oda, Y., Tsuneyoshi, M. and Iwamoto, Y. 2007. Expression of the UV-induced molecule, Gadd45, in atypical fibroxanthoma. Histopathology, 50(7):939-41.

Sakamoto, A., Oda, Y., Yamamoto, H., Oshiro, Y., Miyajima, K., Itakura, E., Tamiya, S., Honda, Y., Ishihara, A., Iwamoto, Y. and Tsuneyoshi, M. 2002. Calponin and h-caldesmon expression in atypical fibroxanthoma and superficial leiomyosarcoma. Virchows Arch., 440(4):404-9.

Sankar, N.M., Pang, K.S., Thiruchelvam, T. and Meldrum-Hanna, W.G. 1998. Metastasis from atypical fibroxanthoma of skin. Med. J. Aust, 168(8):418-9.

Seavolt, M. and McCall, M. 2006. Atypical fibroxanthoma: review of the literature and summary of 13 patients treated with Mohs micrographic surgery. Dermatol. Surg., 32(3):435-41.

Skoulas, I.G., Price, M. andrew, J.E. and Kountakis, S.E. 2001. Recurrent atypical fibroxanthoma of the cheek. Am. J. Otolaryngol., 22(1):73-5.

Smith-Zagone, M.J., Prieto, V.G., Hayes, R.A., Timperman W.W. Jr. and Diwan, A.H. 2004. HMB-45 (gp 103) and MART-1 expression within giant cells in an atypical fibroxanthoma: a case report. J. Cutan Pathol., 31(3):284-6.

Starink, T.H., Hausman, R., Van Delden, L. and Neering, H. 1977. Atypical fibroxanthoma of the skin. Presentation of 5 cases and a review of the literature. Br. J. Dermatol., 97(2):167-77.

Tommasi, S., Swiderski, P.M., Tu, Y., Kaplan, B.E. and Pfeifer, G.P. 1996. Inhibition of transcription factor binding by ultraviolet-induced pyrimidine dimers. Biochemistry, 35(49):15693-703.

Weedon, D. and Strutton, G. 2002. Skin Pathology, Elsevier Science, London.

Weedon, D., Williamson, R. and Mirza, B. 2005. CD10, a useful marker for atypical fibroxanthomas. Am. J. Dermatopathol., 27(2):181.

Westermann, F.N., Langlois, N.E. and Simpson, J.G. 1997. Apoptosis in atypical fibroxanthoma and pleomorphic malignant fibrous histiocytoma. Am. J. Dermatopathol., 19(3):228-31. 
Wick, M.R., Swanson, P.E. and Rocamora, A. 1988. Recognition of malignant melanoma by monoclonal antibody HMB-45. An immunohistochemical study of 200 paraffin-embedded cutaneous tumors. J. Cutan Pathol., 15(4):201-7.

Wilkerson, A.E., Glasgow, M.A. and Hiatt, K.M. 2006. Immunoreactivity of CD99 in invasive malignant melanoma. J. Cutan Pathol., 33(10):663-6.

Winkelmann, R.K. and Peters, M.S. 1985. Atypical fibroxanthoma. A study with antibody to S-100 protein. Arch. Dermatol., 121(6):753-5.

Worrell, J.T., Ansari, M.Q., Ansari, S.J. and Cockerell, C.J. 1993. Atypical fibroxanthoma: DNA ploidy analysis of 14 cases with possible histogenetic implications. J. Cutan Pathol., 20(3):211-5.

Zalla, M.J., Randle, H.W., Brodland, D.G., Davis, J.L. and Roenigk, R.K. 1997. Mohs surgery vs wide excision for atypical fibroxanthoma: follow-up. Dermatol. Surg., 23(12):1223-4. 